\section{Examining mediator and indirect effects of practice of religion in religious attitude on environmental attitude among college students}

\author{
Simeon, Andylyn M. \\ De La Salle University, Philippines (andylyn.simeon@dlsu.edu.ph)
}

Received: 6 September 2020

Revised: 16 October 2020 DOI: $10.5861 /$ ijrse.2020.5724

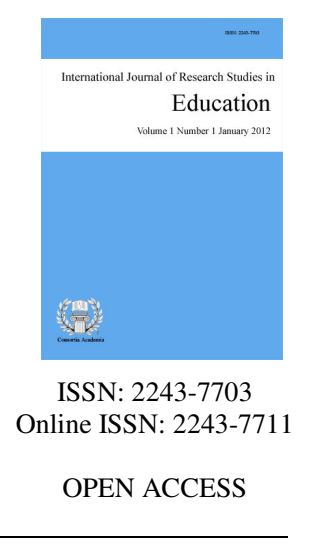

\title{
Abstract
}

This study examines the mediator and indirect effect of the Practice of Religion in Religious Attitude on Environmental Attitude. The participants were 147 college students, 78 were females $\left(\mathrm{M}_{\mathrm{age}}=19.64, \mathrm{SD}=1.01\right)$ and 69 were males $\left(\mathrm{M}_{\mathrm{age}}=20.06, \mathrm{SD}=1.55\right)$. The FSAR Scale (Baring et al., 2018) and the EAI-24 (Milfont \& Duckit, 2010) were used to measure Religious Attitude and Environmental Attitude, respectively. A single-item self-report was used to measure the Practice of Religion. Baron and Kenny's (1986) procedure on mediation analysis was followed and Sobel Test and bootstrapping procedures were used to test the significance of the indirect effect. Results indicated that Religious Attitude predicts Environmental Attitude significantly (path $c=.293, p<.001$ ), and the same significant prediction was observed when the Practice of Religion was regressed on Religious Attitude (path $\mathrm{a}=.440, p<.001$ ). However, a significant prediction between Religious Attitude and Environmental Attitude (path c'=.213, $p=.007$ ) was observed when both the Religious Attitude and Practice of Religion regressed on Environmental Attitude. Thus, only a partial mediation effect was observed. The Sobel Test was significant $(t=1.961, p=.0498)$ and the bias-corrected bootstrap $(n=1000)$ procedure also found the indirect effect significant with a 95\% CI range of 0.0151 to 0.0975 . Therefore, the Practice of Religion has a significant partial mediation effect in the variation of Religious Attitude on Environmental Attitude. The results also suggest the presence of multiple mediating variables between Religious Attitude and Environmental Attitude. Further study using other possible mediator variables is proposed.

Keywords: college students; religious attitude; environmental attitude; practice of religion; mediation analysis 


\section{Examining mediator and indirect effects of practice of religion in religious attitude on environmental attitude among college students}

\section{Introduction}

Pew Research Center in 2015 reported that about 82\% of the people around the world affirm that they belong and practice a certain religion. Religion, according to Merriam-Webster Learners' Dictionary, is the belief in a god or a group of gods; it is also defined as an organized system of beliefs, ceremonies, and rules used to worship a god or a group of gods. Peck (1978) considered religion as a worldview and the challenge he gave to those who are embracing a religion is to ensure that one's worldview is realistic and conforms with the cosmos and aware of the role of every believer in it. And one of the significant social forces that shape one's environmental attitudes is religion (Hunter \& Toney, 2005; Lelkes, 2006). But despite the reality that the world is populated by a majority of the people who declare membership in religion and profess a belief in God and other deities and supernatural beings, how come the planet is in peril now? Can we truly say that religion shapes one's environmental perspective? If so? What is it in religion that promotes a pro-environmental attitude? These are the questions that this paper wishes to respond to, i.e. to study the relationship of religious attitudes and environmental attitudes among College students and what in religious attitude mediates this relationship with environmental attitudes.

Studies have been conducted on the role religion plays on peoples' environmental attitudes, however, the results were inconsistent and contradicting at the most (Harper, 2008). Guth et al. (1995) argue that Catholicism shows a pro-environmental attitude. Slimak and Dietz (2006), however, found out that Christianity does not influence pro-environmental attitudes. And being religious and a member of a Church do not equate with being pro-environment (Kanagy \& Nelsen, 1995; Djupe \& Hunt, 2009). This is supported by Sherkat and Ellision (2007) who argues that being religious does not automatically make one have a pro-environmental attitude and behavior. They also found out that the more liberal a person is in religious terms do not significantly differ with their conservative counterparts with regards to the stance they take on environmental issues. White (1967) advocated the dominion ethic over nature which is stipulated in the Book of Genesis. This view is supported by some studies that show strong Protestant convictions leading to actions against the environment due to this type of ethical relationship between humans and the rest of the creation (Walwyn, 2014) This could have led to the findings of Greeley (1993) that Christian fundamentalists were less willing to preserve the environment contrary to the Catholics whom he found to be are more willing to support pro-environmental efforts. Religious people who are bible literalists also favor environmental utilization than preservation (Milfont \& Duckit, 2010). Arbuckle and Konisky (2015) also found out "that members of Judeo-Christian traditions are less concerned about environmental protection than their nonreligious peers, and that religiosity somewhat intensifies these relationships for evangelical Protestants, Catholics, and mainline Protestants" (p. 1244). Thus, one can not explicitly say what role religion plays in making a stand on environmental issues among those who consider themselves members of any religion.

Hope and Jones (2014) after surveying UK Christians, Muslims, and non-religious persons concluded that all groups possess a strong pro-environmental stance. However, they differ in their motivation. For Christians and Muslims, their pro-environmental stance emanates from their belief that the environment is God's creation and that they are called to take care of it and become stewards of it. On the other hand, among those who profess non-faith or holding secular beliefs, their motivation to become pro-environment is based on theories of evolution and choose to co-exist with all forms of creation by practicing self-regulation. Harper (2008) has listed down religious groups both intra-confessional and inter-confessional who have started efforts in taking the lead in promoting environmental attitudes towards their members.

What we can glean from these studies is the reality that there is a big interest in finding out the best model to 
describe the relationship between religiosity and environmental attitudes. So many variables had been presented that could intervene between religiosity and environmental attitude. An example is considering one's specific religion, also other studies consider the religious person's motivation with regards to pro-environmental attitudes, and also how one regards the environment based on their religious groups' understanding of their respective teachings and scriptures. However, some studies specifically pinpoint the relationship of practicing one's religion as a possible important factor considering the relationship of religious attitude and environmental attitude. It is one of the variables that Guth et al. (1986) attempted to explore together with one's beliefs (particularly one's eschatological view), religious tradition one is espousing and the level of religious commitment.

Horenstein (2012) found out that people who religiously attend services and those who are praying frequently were associated with higher levels of some measures of environmental concern. For him, this could be because these individuals might have exposed themselves to some preaching on becoming more environmentally responsible, especially now that more religious institutions and organizations speak more about it and increasingly responding to the negative situation of the planet. In Indonesia, Mckay et al. (2014) found out that the practice of environmental conservation is more effective if the environmental principles embedded in the Qur'an are also included in the teachings on how to preserve the environment. Thus, this is a call to practice the faith as instructed by their sacred scriptures. Bhatia et al. (2017), conducted a study on how Indians, particularly Buddhist and Muslim Indians, would regard wild animals such as snow leopards and wolves. They found out that Buddhists have more regard towards these animals more than the Muslims. However, in their deeper analysis, they found out further that not all Buddhist participants do but only those who practice the religion. In the end, Bhatia et al. (2017) conclude by recognizing the well-developed teachings and philosophies within religions with regards to taking care of the environment particularly of the wildlife, and calls for religious leaders to take active roles in proclaiming them.

Tucker and Grim (2009) calls for all religious leaders to look at the possible disjunctions between religiosity and environmentalism and reframe them into conjunctures which can eventually bring people with religion to take on specific behavioral practices that will lead to self-transformation and community cohesion which considers the wider environmental and cosmological context. In a youth study, Liobikiene et al. (2016) found out that young Lithuanians are more anthropocentric rather than ecocentric. However, they noticed that "practicing religious young people are more environmentally concerned than those who do not practice or are atheists" (Liobikiene, 2016, p. 89). Recognizing the apparent disagreement on the role of religion on a person's environmental attitude and at the same time, the role of practicing one's religion with regards to their pro-environmental commitments (Tucker \& Grim, 2009; Bhatia et al., 2017; Liobikiene et al., 2016), this study aims to examine the mediator effect of practicing one's religion in one's religious attitude on environmental attitude among college-level Filipino students.

In mediation analysis, a variable mediates the effect of an independent variable on a dependent variable. Baron and Kenny (1986) said that a variable may be said to function as a mediator to the extent that it accounts for the relation between the predictor and the criterion. It explains why a predictor variable can produce change on a criterion variable. When there is a full mediation, the effect of the predictor variable on a criterion variable disappears (equals zero). When there is full mediation, there is strong evidence for a single, dominant mediator. However, if it is not equal to zero, this indicates that there are other multiple mediating factors (Baron \& Kenny, 1986).

Figure 1. Mediation Analysis Model by Baron and Kenny (1986)

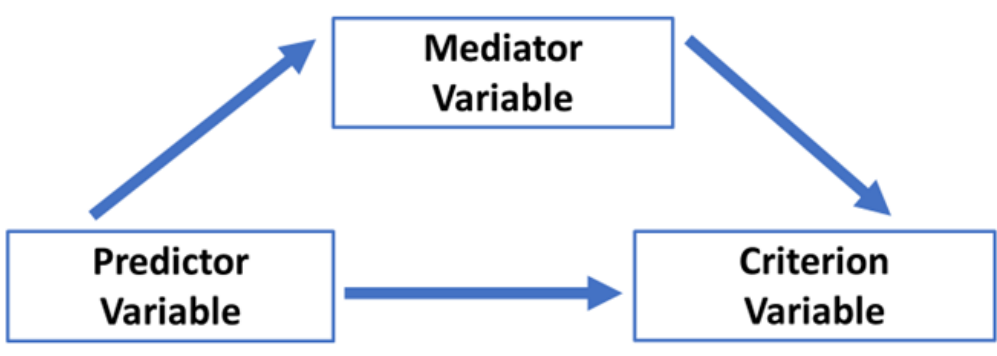


In the current study, the independent variable will be the student's religious attitude. The dependent variable is the student's environmental attitude. Finally, the mediating variable will be the student's self-reported level of practice of religion. The research hypothesis is whether the relationship between Religious Attitude and Environmental Attitude is mediated by one's practice of religion. Thus, the theoretical framework of the current study is shown in Figure 2 below.

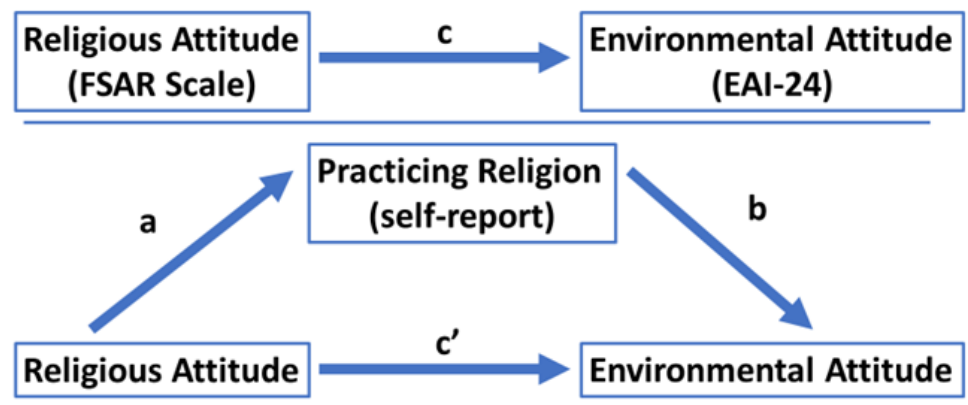

Figure 2. Theoretical framework

The study will test the hypothesis that the practice of religion significantly mediates the effect of religious attitude on environmental attitude. For the hypotheses to be proven, the following conditions must occur: (1) the religious attitude significantly affects one's practice of religion, (2) religious attitude significantly affects environmental attitude in the absence of the variable practice of religion, (3) the practice of religion has a significant unique effect on the environmental attitude, and (4) the effect of religious attitude on the environmental attitude will be equal to zero upon the addition of the variable practice of religion.

\section{Methodology}

\subsection{Participants}

Participants of the study were 147 Filipino undergraduate students. There were 78 females $\left(\mathrm{M}_{\mathrm{age}}=19.64\right.$, $\mathrm{SD}=1.01)$ and 69 were males $\left(\mathrm{M}_{\mathrm{age}}=20.06, \mathrm{SD}=1.55\right)$. Participants were Catholics $(82.67 \%)$, Evangelicals $(12.67 \%)$, Protestants $(3.33 \%)$ and Buddhists (1.33\%). Among them, 38.67\% said that they were regularly practicing their religion, 53\% responded occasionally practicing and $9.33 \%$ reported that they were not practicing their religion at all. The students are coming from different fields of study: $46 \%$ of the participants are into Science and Engineering, 28.67\% are into Social Sciences, 23.33\% are studying Business, and 2\% are taking up Education.

\subsection{Instruments}

The Filipino Students' Attitudes Towards Religion (FSAR) Scale was used to measure the attitude to religion. The scale was developed by Baring et al. (2018). It is a 19-item self-rating Likert scale which can produce an overall score and three subscale scores that measure identity, spirituality, and religiosity. It has a Cronbach's alpha of .82. However, the test can only be given to college-level students who profess an affiliation to any religion.

To measure the environmental attitudes, the Brief Version of the Environmental Attitude Inventory (EAI-24) was used. The EAI-24 was a shorter form of the original EAI which was developed by Milfont and Duckit (2007). In addition to the Generalized Environmental Attitude (GEA) score, the inventory can also generate scores for each of the first-order factors (12 scales) and each of the second-order factors ( 2 scales). Milfont and Duckit (2007) developed this shorter version as a more usable scale for research situations where time is a major constraint. In the development of the inventory, the GEA from EAI-24 has a mean of 4.79 and a standard deviation of .79. Its Cronbach's alpha is .87 and the mean inter-item correlations are equal to .22. 
To measure one's practice of religion, a single self-report item was used on a 3-point scale anchored by regularly practicing and not practicing at all. In this study, the frequency of responses on regularly practicing and moderately practicing were collapsed into one against not practicing at all.

\subsection{Statistical analyses}

Mediation analysis requires a series of simple and multiple regressions and the Sobel Test, which is a specialized t-Test, to measure the mediation or indirect effect. The first linear regression happens when Environmental Attitude is regressed on Religious Attitude. The second linear regression happens when the participants' level of practice of religion is regressed on Religious Attitude. Finally, the last regression is a multiple regression wherein Environmental Attitude is regressed on Religious Attitude and Level of Practice of Religion. For mediation to happen, all regressions should be significant. Finally, to test the significance of the mediator effect, the Sobel test was used.

All data processing was done with Jamovi, version 1.1.9.0 except the Sobel Test which was computed with an online calculator found in http://www.quantpsy.org/sobel/sobel.htm.

In Figure 3 below, Kim (2016) presents the decision-making tree in doing mediation analysis. It shows that for a mediation analysis to happen, it should satisfy the following criteria: 1) the independent variable (x) should predict the dependent variable $(\mathrm{y}) ; 2$ ) the independent variable (x) should predict the moderating variable $(\mathrm{m}) ; 3$ ) when the dependent variable was regressed on the independent variable and the moderating variable, the independent variable should not predict anymore the dependent variable to obtain full mediation, while the mediator variable should significantly predict the dependent variable; 4) however when there are residuals on the part of the independent variable, the mediation is only partial.

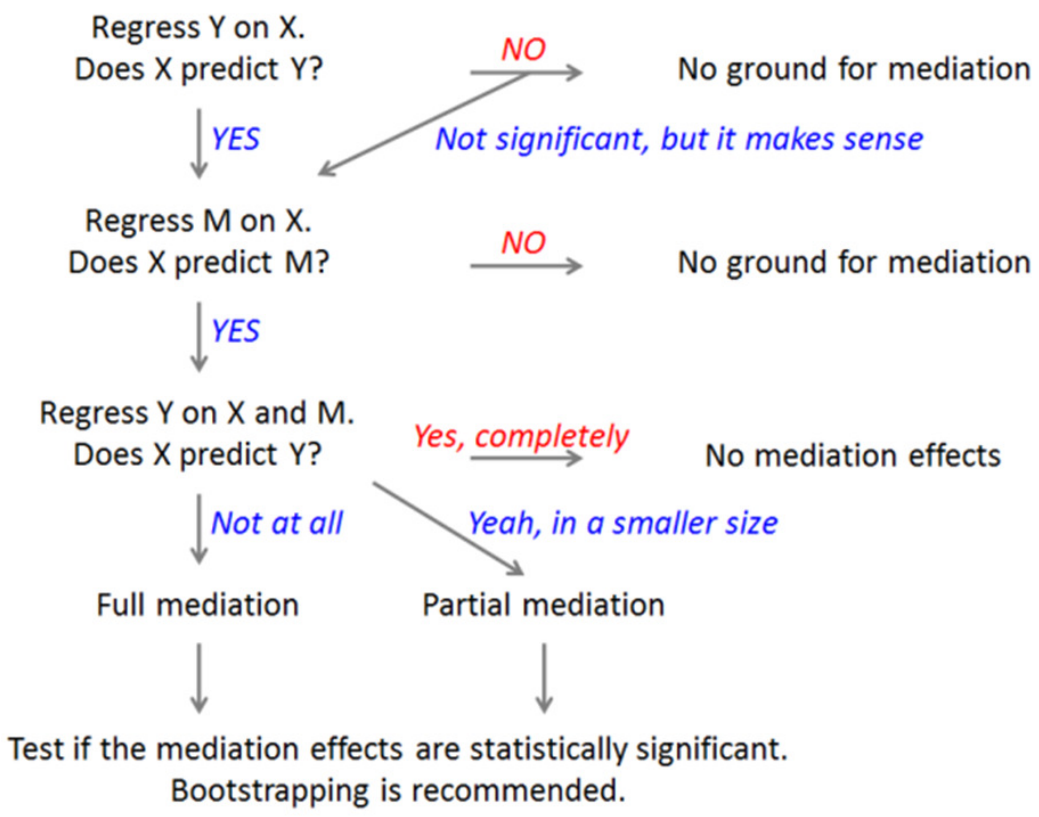

Figure 3. The decision tree in mediation analysis (Kim, 2016).

\section{Results and discussion}

Pearson $r$ correlations were computed among the scores of the participants on FSAR (Religious Attitude), EAI-24 (Environmental Attitude), and on their self-report rating of the level of practice of their religion. Table 1 presents the full correlation matrix. It indicates that Religious Attitude, Environmental Attitude, and Practice of Religion are significantly correlated with each other. 
Simeon, A. M.

Table 1

Pearson r correlations and descriptive statistics

\begin{tabular}{lllccc}
\hline \multicolumn{1}{c}{ Variables } & \multicolumn{1}{c}{$\begin{array}{c}\text { Religious } \\
\text { Attitude }\end{array}$} & $\begin{array}{c}\text { Environmental } \\
\text { Attitude }\end{array}$ & $\begin{array}{c}\text { Practice of } \\
\text { Religion }\end{array}$ & Mean & $S D$ \\
\hline Religious Attitude & --- & & & 3.91 & .644 \\
Environmental Attitude & $.293 * * *$ & ---- & 4.58 & .378 \\
Practice of Religion & $.440 * * *$ & $.275 * * *$ & --- & 1.90 & .295 \\
\hline
\end{tabular}

Note. ${ }^{* * *} p<.0001$.

Table 2 describes the result of the regression analyses. The first simple linear regression (path c) shows that the direct effect between Religious Attitude as the predictor of Environmental Attitude is significant and Religious Attitude explains $8.56 \%$ of the variance of Environmental Attitude. The second simple linear regression (path a), Religious Attitude also significantly predicts the Practice of Religion. Religious Attitude explains $19.4 \%$ of the variance of the Practice of Religion. Finally, the third regression analysis with the Religious Attitude and Practice of Religion as the independent variables predicting Environmental Attitude, the regression model is significant as well explaining 11.2\% of the variation of Environmental Attitude. However, the standardized regression coefficient of Religious Attitude with Practice of Religion on Environmental attitude (patch c') was not equal to zero but simply reduced.

Table 2

Coefficients for the mediating effects

\begin{tabular}{|c|c|c|c|c|}
\hline \multirow{2}{*}{\multicolumn{5}{|c|}{$\begin{array}{c}\text { Testing Paths } \\
\text { Path c: } D V=\text { Environmental Attitude }\end{array}$}} \\
\hline & & & & \\
\hline Religious Attitude (path c) & .172 & .047 & $.0796, .264$ & .293 \\
\hline $\begin{array}{l}\text { Path a: } D V=\text { Practice of Religion } \\
R^{2}=.194, t=5.90, p<.001\end{array}$ & & & & \\
\hline Religious Attitude (path a) & .201 & .0341 & $.134, .296$ & .440 \\
\hline $\begin{array}{l}\text { Path } b \text { and } c^{\prime} D V=\text { Environmental } \\
R^{2}=.112, z=2.35, p=.019\end{array}$ & & & & \\
\hline Religious Attitude (path c') & .125 & .051 & $.0233, .226$ & .213 \\
\hline Practice of Religion (path $b$ ) & .233 & .112 & $.0115, .455$ & .182 \\
\hline $\begin{array}{l}\text { Indirect Effect: } z=2.35, p=.019 \\
\text { (a)*(b) }\end{array}$ & .047 & .0199 & $* .0151, .0975$ & .080 \\
\hline
\end{tabular}

Furthermore, one can see in Table 2 that path c has $\beta$ of .293, and path c' has $\beta$ of .213. Path c' was not equal to zero, however, it was lower than path c. This means that the Practice of Religion partially mediates the relationship between Religious Attitude and Environmental Attitude. To check the significance of the indirect effect a Sobel Test was conducted. Using the unstandardized regression coefficients in computing the Sobel test, the t-statistic was at 1.957 with a $p$-value of 0.0503 , meaning not significant. However, when the $t$-statistic of path a and path $\mathrm{b}$ were used, the $t$-statistic was 1.961 which is already significant at $p .0498$ level. To resolve these conflicting results of the Sobel Test in testing the significance of the indirect effect, a bias-correcting bootstrapping method was used. The $z$ statistic was 2.41 and it was significant at $p=.016$. The $95 \%$ CI range was from .0151 to .0975. Therefore, the indirect effect of the mediator variable Practice of Religion in the relationship between Religious Attitude and Environmental Attitude, albeit partially, was significant.

Almost all the conditions for a full mediation effect were met: 1) Religious Attitude significantly explains the variation of one's Practice of Religion; 2) Religious Attitude significantly explains the variation of Environmental Attitude in the absence of the variable Practice of Religion; 3) The Practice of Religion significantly explains the variation of Environmental Attitude. However, the indirect effect of Religious Attitude on Environmental Attitude was only partial, however significant, upon the addition of the Practice of Religion as a mediator variable. Therefore, the findings support the hypothesis that the Practice of Religion significantly

62 Consortia Academia Publishing (A partner of Network of Professional Researchers and Educators) 
mediates the variations of Religious Attitude on Environmental Attitude, however partial. This partial mediation was observed when the shrinking of the direct effect of Religious Attitude on Environmental Attitude still left behind significant residual results. Kim (2016) argues that full mediation rarely happens in practice. Therefore, we can say from this study that practicing one's religion already impacts one's environmental attitudes instead of religious attitude.

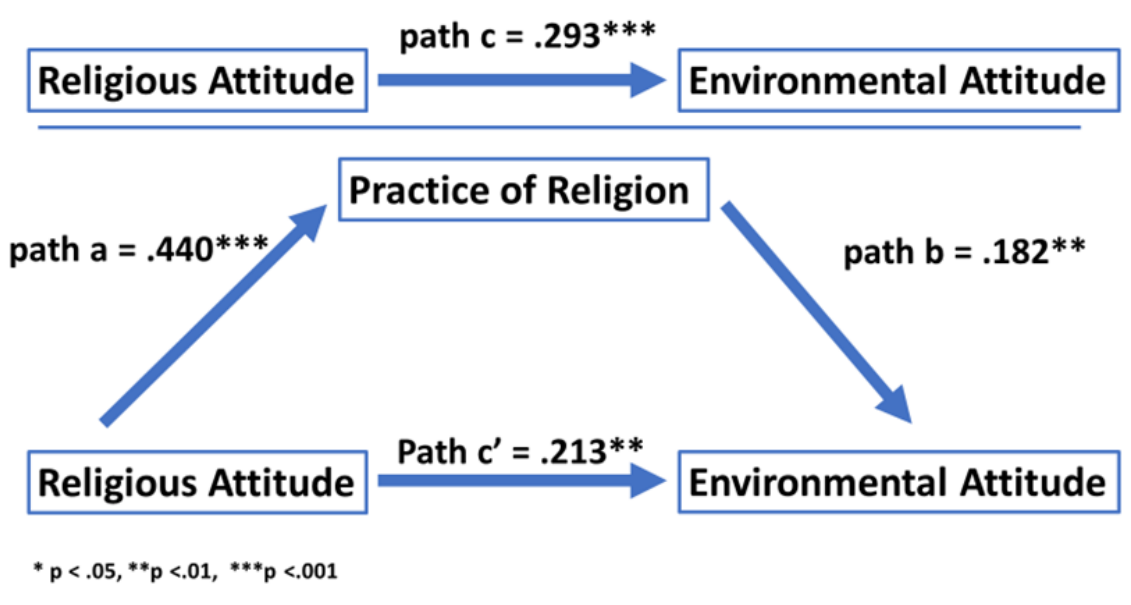

Figure 4. Standardized Regression Coefficients of paths and their significance.

Another significant finding of the study is that the variation of Religious Attitude on Environmental Attitude is mediated by multiple mediating factors given that there was still significant residual effect coming from Religious Attitude that was not fully explained by the Practice of Religion. This finding, then, calls for further studies which are aimed toward looking for other possible mediating variables that can fully explain the relationship between Religious Attitude and Environmental Attitude.

\section{Conclusion}

The study was motivated to see whether the practice of religion can significantly mediate the effect of religious attitude on environmental attitude as already observed by Horenstein (2012), Bhatia et al. (2016) among the Buddhists, and Liobikiene et al. (2017) with the young Lithuanians. This study corroborates their findings and supports their theories. It was observed in this study that the Practice of Religion significantly accounts for the variation of Religious Attitude on Environmental Attitude, albeit partially.

This also supports the findings of Tucker and Grim (2009) who call for all religious leaders to look at the possible disjunctions between religiosity and environmentalism and reframe them into conjunctures which can eventually bring people with religion to take on specific behavioral practices that will lead to self-transformation and community cohesion which considers the wider environmental and cosmological context. The findings of this study further support that of McKay et al. (2014) who found out that the practice of environmental conservation is more effective if the environmental principles embedded in the Qur'an are also included in the teachings on how to preserve the environment.

Therefore, this study implies the need for a more aggressive call from within the religious communities, particularly its leaders, to consider those who are practicing their religion as possible allies in promoting pro-environment attitudes among their members. To generalize the proposal of McKay et al. (2014), there is a need to go back to the rich traditions of every religion and look from deep within it the high regard of their religion with the environment. And from here, as proposed by Tucker and Grim (2009), to look for conjunctures and examples of behavioral practices coming from the teachings of their respective religious communities that support the pro-environmental stance. This study has shown that part of practicing one's religion or faith is to have pro-environment attitudes and those who regularly attend church services or remaining faithful to the 
teachings and practices of their respective religions are already potential partners in promoting pro-environmental values and beliefs. And this is what Pope Francis (2015) speaks about in his encyclical Laudato Si' when he addressed all of humanity to work together in seeking sustainable and integral development and to work together in building our common home (\#13).

Having college students as the participants in this study, it also implies the need to create opportunities for these religiously practicing young adults in colleges and universities in getting them involved in pro-environmental actions. This can be taken together by the university's social engagement office, religious studies department, and pastoral or campus ministry office.

Future studies are still desired given that the relationship between Religious Attitude and Environmental Attitude was found to be mediated by multiple mediating factors. Other variables that can be considered are the involvement of the college students in religious youth groups and their level of participation in the group. Other possible variables that can explain the relationship between religious attitude and environmental attitude are the ones suggested by Guth et al. (1986). These variables are one's beliefs (particularly one's eschatological view), religious tradition one is espousing and level of religious commitment (Guth et al., 1986).

Going back to the studies of White (1967), Greeley (1993), and Milfont and Duckit (2010), one can also see the possible effect of one's way of interpreting and understanding the Bible among the Christians as a possible mediating variable between Religious Attitude and Environmental Attitude as Milton and Duckit (2010) observed that Christians who are bible literalists favor environmental utilization than preservation as they follow the ethic of humanity's dominion over created things.

\section{References}

Arbuckle, M. B., \& Konisky, D. M. (2015). The role of religion in environmental attitudes. Social Science Quarterly, 96(5), 1244-1263. https://doi.org/10.1111/ssqu.12213

Baring, R., Sarmiento, P., Sibug, N., Lumanlan, P., Bonus, B., Samia, C., \& Reysen, S. (2018). Filipino college students' attitudes towards religion: An analysis of the underlying factors. Religions, 9(3), 85. https://doi.org/10.3390/re19030085

Baron, R. M., \& Kenny, D. A. (1986). The moderator-mediator variable distinction in social psychological research: Conceptual, strategic, and statistical considerations. Journal of Personality and Social Psychology, 5, 1173-1182. https://doi.org/10.1037/0022-3514.51.6.1173

Bhatia, S., Redpath, S. M., Suryawanshi, K., \& Mishra, C. (2017). The relationship between religion and attitudes toward large carnivores in northern India? Human Dimensions of Wildlife, 22(1), 30-42. https://doi.org/10.1080/10871209.2016.1220034

Djupe, P. A., \& Hunt, P. K. (2009). Beyond the Lynn white thesis: Congregational effects on environmental concern. Journal for the Scientific Study of Religion, 48(4), 670-686. https://doi.org/10.1111/j.1468-5906.2009.01472.x

Greeley, A. (1993). Religion and attitudes toward the environment. Journal for the Scientific Study of Religion, 32(1), 19-28. https://doi.org/10.2307/1386911

Guth, J., Green, J., Kellstedt, L., \& Smidt, C. (1995). Faith and the environment: Religious beliefs and attitudes on environmental policy. American Journal of Political Science, 39(2). 364-382. https://doi.org/10.2307/2111617

Harper, C. L. (2008). Religion and environmentalism, religion and the environment. Journal of Religion \& Society, Supplement 3, 5-26.

Hope, A. L. B., \& Jones, C. R. (2014). The impact of religious faith on attitudes to environmental issues and Carbon Capture and Storage (CCS) technologies: mixed-methods study. Technology in Society, 38, 48-59. https://doi.org/10.1016/j.techsoc.2014.02.003

Horenstein, A. (2012). The relationship between religious attitudes and concern for the environment [Master's Thesis]. Columbia University.

64 Consortia Academia Publishing (A partner of Network of Professional Researchers and Educators) 
Mediator and indirect effects of practice of religion in religious attitude on environmental attitude

Hunter, L. \& Toney, M. (2005). Religion and attitudes toward the environment: A comparison of Mormons and the general US population. The Social Science Journal, 42(1), 25-38. https://doi.org/10.1016/j.soscij.2004.11.003

Kanagy, C. L., \& Nelsen, H. M. (1995). Religion and environmental concern: Challenging the dominant assumptions. Review of Religious Research, 37(1), 33-45. https://doi.org/10.2307/3512069

Kim, B. (2016). Introduction to mediation analysis. Retrieved from https://data.library.virginia.edu/introduction-to-mediation-analysis/

Lelkes, O. (2006). Knowing what is good for you. Empirical analysis of personal preferences and the "objective good. Journal of Socio-Economics, 35, 285-307. https://doi.org/10.1016/j.socec.2005.11.002

Liobikienè, G., Niaura, A., Mandravickaitè, J., \& Vabuolas, Ž. (2016). Does religiosity influence environmental attitude and behaviour? The case of young Lithuanians. European Journal of Science and Theology, 12(1), 81-96.

McKay, J. E., Mangunjaya, F. M., Dinata, Y., Harrop, S. R., \& Khalid, F. (2014). Practice what you preach: A faith-based approach to conservation in Indonesia. Oryx, 48(1), 23-29. https://doi.org/10.1017/s0030605313001087

Merriam-Webster. (n. d.). Religion. In Merriam-Webster's LearnersDictionary.com. Retrieved from https://www.learnersdictionary.com/definition/religion

Milfont, T. L., \& Duckitt, J. (2007). A brief version of the environmental attitudes inventory. Unpublished manuscript.

Milfont, T. L., \& Duckitt, J. (2010). The environmental attitudes inventory: A valid and reliable measure to assess the structure of environmental attitudes. Journal of Environmental Psychology, 30(1), 80-94. https://doi.org/10.1016/j.jenvp.2009.09.001

Peck, M. S. (2003). The road less traveled: a new psychology of love, traditional values, and spiritual growth. New York: Touchstone.

Pew Research Center. (2015). The future of world religions: Population growth projections, 2010-2050. Retrieved from https://www.pewforum.org/2015/04/02/religious-projections-2010-2050/

Pope Francis. (2015). Encyclical letter Laudato Si' of the Holy Father Francis (1st ed.) Retrieved from http://www.vatican.va/content/francesco/en/encyclicals/documents/papa-francesco_20150524_enciclica -laudato-si.html

R Core Team. (2018). R: A language and environment for statistical computing. [Computer Software]. Retrieved from https://cran.r-project.org/

Sherkat, D., \& Ellison, C. (2007). Structuring the religion-environment connection: Identifying religious influences on environmental concern and action. Journal for the Scientific Study of Religion, 46, 71-85. https://doi.org/10.1111/j.1468-5906.2007.00341.x

Slimak, M. W., \& Dietz, T. (2006). Personal values, beliefs, and ecological risk perception. Risk Analysis, 26, 1689-1705. https://doi.org/10.1111/j.1539-6924.2006.00832.x

The Jamovi project. (2019). Jamovi. (version 1.1)[Computer Software]. Retrieved from https://www.jamovi.org

Tucker, M., \& Grim, J. (2014). Overview of world religions and ecology. Retrieved from http://fore.yale.edu/religion/\#text1

Walwyn, E. S. (2014). Culture and conservation in the sacred sites of coastal Kenya [Doctoral dissertation]. University of Kent.

White, L. (1967). The historical roots of our ecologic crisis. Science, 155(3767), 1203-1207. https://doi.org/10.1126/science.155.3767.1203 
Simeon, A. M.

66 Consortia Academia Publishing (A partner of Network of Professional Researchers and Educators) 